\title{
The Need for the Islamization of Knowledge in Accounting 1
}

\author{
JamaluddinMajid \\ Safri Haliding
}

\begin{abstract}
The Need For The Islamization of Knowledge In Accounting. This article tries to analyze the term "Islamization of knowledge method through accountancy. The economic system and the foundation of philosophy its system may influence the accounting practice that Islamic worldview provides the original source of revelation in a Muslim society by using Islamic literally of being the adherents to Islam due to be vicegerents of god and providing accountability in all aspects. Islam as a way of life, covering all activities and economic activities as accounting as well are only small part of Islam, through Al Quran and Al Hadits. In terms of developing of Islamic accounting system that as social science and institution may provide a way to satisfy its social economic objective in order to meet the benefit in this world and hereafter. Since many scandals and fraudulent in accounting practices, accounting should be Islamized. Hence, Islamic accounting is needed to bring solutions in business and financial activities in order to achieve the objective of Shariah and Islamic goals of maslahah (social benefit).
\end{abstract}

Keywords:Islamization of Knowledge, Islamization of Accounting, Islamic Accounting

Abstrak. Pentingnya Islamisasi Pengetahuan Dalam Akuntansi. Tulisan ini mencoba untuk mengkaji metode Islamisasi pengetahuan pada disiplin ilmu akuntansi. Sistem dan landasan filosofi ekonomi dapat mempengaruhi praktik akuntansi sebagai turunan dari ilmu ekonomi. Dalam perspektif Islam, Islamic worldview atau pandangan dunia Islam yang bersumber dari Ilahi merupakan sumber literatur yang paling tepat dan sesuai dengan syariah untuk Islam. Islam sebagai jalan hidup, mencakup semua aspek kehidupan dan kegiatan ekonomi demikian halnya dengan akuntansi sebagai salah satu disiplin ilmu dengan berlandaskan pada Al-Quran dan Al Hadits. Sebagai salah satu ilmu sosial, maka dalam pengembangan sistem akuntansi Islam harus berdasarkan pada tujuan sosial ekonomi dalam rangka tercapainya kebahagian di dunia dan akhirat. Dengan begitu banyak skandal dan kecurangan dalam praktek akuntansi, maka akuntansi harus diIslamisasi agar akuntansi dapat memberikan solusi dalam kegiatan bisnis dan jasa keuangan agar maqashid syariah dan maslahah dapat tercapai.

Kata Kunci: Islamisasi Pengetahuan, Islamisasi Akuntansi, Akuntansi Islam

\footnotetext{
${ }^{1}$ Naskah diterima: 10 Oktober 2013, direvisi: 12 Nopember 2013, disetujui: 20 Nopember 2013

JamaluddinMajid is an accounting lecturer at Universitas Islam Negeri (UIN) Alauddin, Makassar, email: jamal_majid55@yahoo.com

Safri Haliding, lecturer at Faculty of Economics, Muhammadiyah University of Makassar, Indonesia and part time lecturer at UIN Alauddin Makassar and doing his master in accounting at International Islamic University Malaysia (IIUM) . Email: safrihaliding@yahoo.com and safrihaliding@gmail.com
} 


\section{INTRODUCTION}

Western systems have been failed in Islamic society. Muslim countries became independence from colonial control in authority of political perspective that providesIslamic society to see back of the Islamic solution and alternatives (Haneef, 2005). The effect of colonialism to Muslim countries is influence the adoption of western system in political and social economic model that namely as westernization. As Muslim society Islamic perspective in all aspects of Muslims life is very important in order to meet Shariah rules and principles of social benefit (maslaha) and human welfare in the world and hereafter. Baydoun \& Willet (1997) assert that Al Quran \& Al Hadits are source of Islamic Shariah provide the real guidance to govern the live of Muslims. Therefore, Islamization of knowledge is needed in terms of Islamic worldview in this world and hereafter.

Islamization of knowledge has been discussed by some scholars. For instance, Haneef (2005) mentions such as Al Attas (1978), Faruqi (1982), Davies (1991), Abu Fadl (1988), Brohi (1993). Those scholars have own idea and different perspective to develop of Islamization of knowledge. However, mostly they agreed that the one way of process Islamization of knowledge is to bring Al-Quran and Al Hadits into the philosophy of knowledge as Islamic worldview. Rahman (2010) argues that both worldly aspect and the religion aspect are covered by the worldview of Islam. Worldview may affect the quality of life in way we think and behave to see the whole of the world that as Muslims we may get the guidance and idea of worldview from the Al Quran known as the Quranic worldview (Hamid, 2004).

Rahman (2010) states that the economic system and the foundation of philosophy its system may influence the accounting practice that Islamic worldview provides the original source of revelation in a Muslim society by using Islamic literally of being the adherents to Islam due to be vicegerents of god and providing accountability in all aspects. In term of accountability, accounting as one of modern knowledge is becoming of the process of Islamization as a responsibility to both Muslim society and God.

This article tries to analyze the term "Islamization of knowledge method through which accounting can be Islamized. This article proceed with the explanation about the concept of Islamization of knowledge as general, the need of Islamic accounting, Islamization of accounting, the existing method through which accounting can be Islamized, issues and challenge on Islamization of Accounting and followed by conclusion of the paper.

\section{THE CONCEPT OF ISLAMIZATION OF KNOWLEDGE}

Indirectly Muslim society follows the western worldview by learning and applying the knowledge and sciences of contemporary universities or higher institutions that temporary knowledge is needed to Islamize from the Western worldview of knowledge built on them (Haneef, 2005). In addition, Haneef (2005) states that the process of Islamization of knowledge may provide the evaluation, sifting, and modification of western's fundamentally on knowledge concept and structure.

The perceptions of knowledge from western worldview are some of them out from philosophy of science of Al Quran perspective. Hamid (2004) states that the development of people mind currently may provide the assumption that the power and the right are independently chosen as human being and religion is only human imagination, they have run away from religion and belief in God that. In addition, the power of reason and logic it 
self is as human beings, the power must consider to it self limited as knowledge as well to find a valid worldview (Hamid, 2004).

Golshani pointed out of the some principles of doing any kind of scientific activities as follows: firstly, the principles of monotheism (at tawhid), it means that all scientific activities in order to get and recognize the wise Creator and Governor of the universe of Quranic worldview and the symbol of the Creator are all nature and knowledge. Secondly, the reality of the external world, it means that world is to be using as subject of knowledge and sciences of the Quranic worldview. Thirdly, Limitation of human knowledge, it means that human has limitation of getting and understanding of the knowledge, also unseen is exist of supernatural truth in this world that there is a hereafter life.

Some scholars try to see the rationale for IOK. As quoted by Haneef (2005) of Muslim's scholars perspective for rationale IOK, Brohi's argument (1993) that modern knowledge provided inconsistent from the framework of Islamic worldview as supports Rabab (1995), who tries to see rationale of IOK from the assumptions that in modern societies, assumption of social sciences may be unacceptable from Islamic worldview.

Regarding to the meaning of Islamization of knowledge that Haneef (2005) mentions some scholars' definition, Al-Attas (1978) defined IOK as "the deliverance of knowledge from its interpretation based on secular ideology; and from meaning and expression of the secular"; Faruqi (1982) sees that IOK as "recasting knowledge as Islam relates to it"; Davies (1991) defined IOK as " civilizational project of rethinking, taking the Quran as the frame of reference". Haneef (2005) states that the conclusion of the meaning of Islamization of knowledge from the elaboration above, the concept of IOK relates to the Islamic ontology framework and Islamic epistemological framework as the methodology in order to provide the true meaning and presenting the knowledge. In addition, ontology in Islamic perspective is very important in terms of that ontology may provide the true of existence of knowledge that ontology may bring the information of true source of knowledge due to Al quran and Al Hadists and also concept of the Tauhid (only on God). However, the process of IOK in society needs time and commitment form Muslim society itself to support of the process of Islamization of knowledge that the level of Muslims understanding for the urgency of IOK is different and also they may reject IOK in terms of their western worldview has been become a way of life and exist in muslims mind.

In terms of the process that there are some steps to Islamize knowledge. The most famous of involving the IOK is the faruqi's 1982 work-plan mentions the following steps: 1. Mastery of the modern disciplines. 2. Discipline survey that presents the history, methodology, and main contribution of that discipline, including a bibliography. 3. Mastering the Islamic legacy: the anthology. 4. Mastery of the Islamic legacy: the Analysis. 5. Establishment of the specific relevance of lslam to the disciplines covering what the legacy has contributed to the range of issues envisaged by the discipline, the legacies achievements and shortcomings vis-à-vis the 'vision and scope of the discipline', why it is so and what can be done. 6. Critical Assessment of the Modern Discipline. 7. Critical assessment of the Islamic legacy. 8. Survey of the Ummah's major problems requiring insight, good judgment and knowledge of both the legacy and modern knowledge. 9. Survey of the problems of humankind as IOK is seen to not only be for Muslims but for all humanity. 10. Creative analysis and synthesis between the Islamic legacy and modern disciplines. 11. Recasting the disciplines under the framework of Islam. 12. Dissemination 
of Islamized Knowledge where ideas and thought of Muslims involved in IOK must be available to all.

Another scholar of $\mathrm{IOK}$ is Al-Attas that he sees the process to Islamize the knowledge by two way as the following steps: 1 . Isolation of key elements that make-up western culture and civilization from every branch of knowledge. 2. Infusion the Islamic elements and key concepts into all branches of knowledge. That Al-Attas's concepts are an epistemological and methodological concern.

Islamizationof accounting that both of Faruqi's 12 point plan and Al-Attas concepts could be used to development the accounting in Islamic perspective. However, Rahman's view that Faraqu's plan is ideally to develop accounting in Islamic perspective compared to Al-Attas's concept that takes many processes.

Based on the author's understanding that accounting should be Islamized, since many scandals and fraudulent in accounting practices. Hence, Islamic accounting is needed to bring solutions in business and financial activities in order to achieve the objective of Shariah and Islamic goals of maslahah (social benefit). Hence, Author believe that Faraqu's plan of IOK is one of the best way to develop Islamic accounting to provide accountants who may mastery of accounting first then develop a mastery Islamic legacy on in accounting perspective in order to provide Islamic epistemological framework as the methodology in order to provide the true meaning and presenting the knowledge in Islamic perspective.

\section{THE NEED OF ISLAMIC ACCOUNTING}

The need for Islamic accounting may refer to two indicators those push and pull factors (Hameed, 2000 as quoted by Ratmono, 2005). Pull factors provide the need for islamic accounting to Muslims user and Islamic institution due to convention accounting improperly to Islam society (Ratmono, 2005). In addition, Hameed (2000) pointed out pull factor into two: first, The Islamization of knowledge factor that provides the theoretical imperative for Islamic accounting. Second, The establishment of Mulsims and Islamic institutions that is the practical imperative for the development of Islamic accounting.

In addition,Hameed (2000) as quoted by Ratmono (2005) divided the need of Islamic accounting from push factors into six parts: 1 . The objective of conventional accounting based on decision usefulness may not be accepted from Islamic worldview. 2. Neither the assumption of pristine liberal economic democracy nor the developed exchange economy with a developed stock market in valid for many Muslim countries. 3 . The accounting principles on conventional accounting reports are prepared may be unsuitable for the direct and indirectly for reporting Zakat as one of the objective of Islamic accounting. 4. The problem with historical income model becomes more problematic in Muslim environment. 5. The negative economic and social consequences of conventional accounting to environment, society, individuals are unacceptable from Islamic worldview. 6. Conventional management systems may lead to behavior that is disfunctional not only in terms of organizational goals achievement but in terms of the moral and ethical consequences of individual and group Islamic behavior.

Following from the above factors that there is a need for developing Islamic accounting that more relevant to Muslim society, socio-economic and Islamic worldview in order to meet the objective of Islamic principles and rules. 


\section{THE PROCESS OF THE ACCOUNTING ISLAMIZATION}

Rahman (2012) defined Islamic accounting as "the process of identifying, measuring, and communicating economic and other relevant information inspired by Islamic Worldview and complied with Shari'ah Islamiyah to permit informed judgements and decisions by potential and expected users information to enhance social welfare and achieveMardhatillah(blessings from Allah)".

In addition, Hameed (2009) defined Islamic accounting as the "accounting process which provides appropriate information (not necessary limited for financial data) to stakeholders of an entity which will enable them to ensure that the entity is continuously operating within the bounds of the Islamic Shariah and delivering its socioeconomic objective". Like conventional accounting that Islamic accounting is a tool a well in providing the business information, in way to accountability to God as Muslims (Hameed, 2009).

Hameed (2009) pointed out that the differences between conventional accounting and Islamic accounting as following: 1 . The objective of providing the information, 2 . What type of information is identified, and how is it measured and valued, recorded and communicated, 3. To whom is it communicated (the users). For Islamic accounting the information may unsure the social-economic and religious events and transactions as objective of Shariah compliance.

Rahman (2010) states that in terms of accounting measurement in conventional accounting takes consideration to the acquisition cost or historical cost unlike to Islamic accounting that focuses on current cost due to Zakat determination as issues in fairness and justice that Zakat valuation is subjected to the current market value. Baydoun and Willet (1997) assert that the obligation on paying Zakat for Muslim provides a distinctive model of Islamic accounting information systems.

Rahman (2010) states that with regards to the disclosure requirements in Islamic accounting may provide the objective of disclosure for Islamic organization, Rahman pointed out as followings: the disclosure laid down by Shariah for the firm to avoid riba and pay Zakat, the objectives are based on inferred general requirement that can be referred to as social accountability and full disclosure. The way to full disclosure is followed to social accountability as part of serving to God of providing the social economic justice and also does not mean that full disclosure to show every single detail transaction (Rahman, 2010).

Rahman (2003) argues that accounting on Islamic perspective in Muslim society, in way of accountant to provide the financial information to user is not only as service to the users and public at large, but information is provided to society must take consideration to accountability in order to follow the God's commandments.

Since many scandals and fraudulent in accounting practices, accounting should be Islamized. Hence, Islamic accounting is needed to bring solutions in business and financial activities in order to achieve the objective of Shariah and Islamic goals of maslahah (social benefit). In addition, There are some methods through which accounting can be Islamized, these methods are only a part of developing Islamic accounting which are deduction from Islamic teachings approach, contemporary accounting based approach (see, Yaya, 2004), and also could be used strategic work plan approach, which we have developed based on Faruqi's Strategic Work Plan (1989) in Islamization of knowledge. In terms of Islamic socioeconomics objectivethat the approaches may provide the inherent weakness in applying the Islamic accounting (Yaya, 2004). 
The first approach is called a normative approach that means bring a deduction from Islamic teaching. Yaya (2004) argue that this approach may follow the what "ought to be" the objective of financial accounting, that may as additional value to the western objective of financial accounting to be appropriate for Islamic business organizations. According to AAOIFI (2006), by using this approach the objective of Islamic accounting based on the Islamic principles and its teaching that could be used as these objectives in relation to contemporary accounting thought. In addition, Karim (2005) states that by using this approach the western worldview of secular system on accounting thought could be minimized on the objective of Islamic accounting.

This approach uses the proponent "what is". Yaya (2004) assert that this approach is a process of adopting the currently western financial accounting into accounting for Islamic institution without violating the objective of Islamic principles. In conventional accounting only economic event and transaction. The development of this approach provides the moral dimensions which are out from conventional accounting (Karim, 1995). Moral and ethics in accounting may lead to provide proper practices in accounting in terms of human accountant. In addition, Rahman (2012) argue that accountant may fulfill the religion obligations (HablumMinallah) as muslim accountant in order to require the good relationship both superior (management) and relationship to God by value of truthfulness, fairness, tolerance and uprightness.

The AAOIFI has been developed the Islamic accounting framework, one of that is objective of Islamic accounting which based on the decision usefulness approach. On the other hand, some scholars use different approaches (i.e. Hameed, 2000a; Adnan and Gaffikin, 1997). Lewis (2001) argues that Islamic accounting may follow the Islamic law in terms of the accounting principles and postulates in order to develop the proper accounting theory.

Therefore, Lewis (2001) provides approaches for the objective of Islamic accounting as follows: First, Establish objectives based on the spirit of Islam and its teaching and then consider these established objectives in relation to contemporary accounting thought. Second, Start with objectives established in contemporary accounting thought, test them against Islamic shari'ah, accept those that are consistent with shari'ah and reject those that are not.

Yaya (2004) pointed out the objective of Islamic accounting into some issues as followings: first, decision usefulness, Yaya (2004) argues that in terms of Islamic Accounting's objectives of The AAOIFI, the contents and goals are likely the same with currently conventional accounting that focus on providing information system for users. Second, stewardship, Mirza and Baydoun (2000) state that in reporting of Islamic accounting may take consideration to to external parties and; third, accountability, Adnan and Gaffikin (1997) argues that Zakat as the primary objective of accountability in Islamic Accounting and Hameed (2000) suggests that the primary objective is the Islamic accountability.

Follows, the writer would like to highlight discuss some of problem rising in the method of Islamization of accounting and the development of Islamic accounting itself. Firstly, the issues in Islamic worldview on accounting. At this point, the process of Islamization of knowledge in accounting may provide some obstacles and times. The understanding in Muslim concept in business and culture of Muslim society are some challenge to develop Islamic accounting due to western value has been existed in Muslims 
mind and activities. Therefore, Islamic Accounting should be derived from the philosophy worldview and values of Islam.

Second issue is theoretical building for Islamic accounting. It is needed to take more attention on methodology that could be implemented in practices (Kamla, 2009; Haniffa \& Hudaib, 2010). For example: Islamic accounting practices should not be a merely changing cover and name from conventional bank to Islamic bank but the reality is still out from Shariah objective and principles (Kasim et al. 2009; Napier, 2009). Kamla (2009) states that "differences between Islamic accounting and banking and conventional counterparts in the Islamic accounting literature are usually reduced to technical (rather than social) dimensions related to the prohibition of interest and Zakah calculations" (also see Rahman and Goddard, 1998; Baydoun and Willett, 2000; Lewis, 2001; Sulaiman and Willett, 2001).

Since the literatures in accounting and Islam, therefore, I try argue that in practice of Islamic accounting may focus on issues in ethics particularly on Islamic financial products and Islamic banks that in the reality in business transactions some businessmen may not really take consideration on Islamic principles and rules in terms of profit oriented. Therefore, developing a particularly regulation may be really needed and also supervisory is very important to achieve the Shariah objective in maslahah.

\section{CONCLUSION}

The Islamization of knowledge is a emerging issues on process to convert all knowledge that may refer to Al Quran and Al Hadits as basis source of knowledge and philosophy that to build the Muslim mind from thought crisis and the malaise of Muslim. Islam as a way of life, covering all activities and economic activities as accounting as well are only small part of Islam, through Al Quran and Al Hadits. in terms of developing of Islamic accounting system that as social science and institution may provide a way to satisfy its social economic objective in order to meet the benefit in this world and hereafter.

Since many scandals and fraudulent in accounting practices, accounting should be Islamized. Hence, Islamic accounting is needed to bring solutions in business and financial activities in order to achieve the objective of Shariah and Islamic goals of maslahah (social benefit). In addition, there are some methods through which accounting can be Islamized, these methods are only a part of developing Islamic accounting whichare deduction from Islamic teachings approach, contemporary accounting based approach,and also could be used strategic work plan approach, which we have developed based on Faruqi's Strategic Work Plan (1989) in Islamization of knowledge that has been used some universities such International Islamic University Malaysia.

\section{REFERENCE}

AAOIFI. 2010. Accounting and Auditing Standards for Islamic Financial Institutions. Manama, Bahrain: Accounting and Auditing Organization for Islamic Financial Institutions.

Al Faruqi, I.R. 1988. Islamization of knowledge: Problems, principles and perspective in Islam; Source and Purpose of Knowledge. Herndon Virgina: International Institute of Islamic Thought.

Golshani, M. 1989. "Philosophy of Science from the Quranic Perspective" in Towards Islamization of Disciplines. Herndon Virginia: International Institute of Islamic Thought 
Hameed, S. 2009. Accounting and Auditing for Islamic Financial Institutions. Kuala Lumpur: INCEIF.

Hameed, S., and Yaya, R. 2005. The Emerging Issues on The Objective and Characteristic of Islamic Accounting for Islamic Business Organizations. Malaysian Accounting Review, Vol. 4, No. 1, pp. 75-93.

Hamid, A. W. 2004. Islam: The Natural Way. London: MELS

Haneef, M. A. 2005. A Critical Survey of Islamization of Knowledge. Kuala Lumpur: International Islamic University Malaysia

Haniffa, R. and Hudaib, M. 2002. A theoretical framework for the development of the Islamic perspective of accounting. Accounting, Commerce and Finance: The Islamic Perspective Journal, Vol. 6, No. 1/2, pp. 1-71.

---------.-- 2010. The Two Ws of Islamic Accounting Research. Journal of Islamic Accounting and Business Research, Vol. 1 No. 1, pp. 5-9.

Hasan, Z. 1998. Islamization of Knowledge in Economics: Issues and Agenda. Kuala Lumpur: IIUM Journal of Economics and Management, vol. 6, no.2, pp. 1-40.

Kamla, R. 2009. Critical insights into contemporary Islamic accounting. Critical Perspectives on Accounting, Vol.20, pp. 921-932.

Kamla, R., Gallhofer, S., and Haslam, J. 2006. Islam, Nature and Accounting: Islamic Principles and the Notion of Accounting for the Environment. Accounting Forum, Vol.30, pp. 245-265.

Karim, R.A.A. 1995. The Nature and Rationale of a Conceptual Framework for Financial Reporting by Islamic Banks. Accounting and Business Research. Vol. 25 No.100, pp.285-300.

---------. 2001. International Accounting Harmonization, Banking Regulation, and Islamic Banks. The International Journal of Accounting, 36, pp. 169-193.

Kasim, N. B., et.al. 2009. Shariah Auditing in Islamic Financial Institutions: Exploring the Gap Between the "Desired" and the "Actual". Global Economy \& Finance Journal, Vol. 2, No. 2, pp. 127-137.

Lewis, M. K. 2001. Islam and Accounting. Accounting Forum, Vol. 25 No. 25, pp. 103-127

Maali, M., and Napier, C. 2010. Accounting, religion and organizational culture: the creation of Jordan Islamic Bank. Journal of Islamic Accounting and Business Research, Vol. 1 No. 2, pp. 92-113.

Mirza, M \&Baydoun, N. 2000. Accounting policy in a riba free environment. Accounting, Commerce and Finance: The Islamic Perspective Journal. Vol. 4. No. 1, pp. 30-40.

Pomeranz, F. 1997.The Accounting and Auditing Organization for Islamic Financial Institutions: An Important Regulatory Debut. Journal of International Accounting, Auditing \& Taxation, 6( 1): 123-130.

Rahman, A. R. A. 2003. Ethics in Accounting Education: Contribution of the Islamic Principle of Maslahah. IIUM Journal of Economics and Management, vol. 11, no.1, pp. 1-18. Lumpur: CERT

Ratmono, D. 2005. "The nature of Islamic Accounting and Cultural Influence of Perceived Usefulness of The Islamic Corporate Reporting: Perception of Muslim Accounting Academicians in Java". Unpublished Masterthesis, University of Diponegoro, Semarang, Indonesia. 
Sulaiman, M., and Willett, R. 2001. Islam, Economic Rationalism and Accounting. The American Journal of Islamic Social Sciences, Vol. 18, No.2, pp. 1-36.

Sulaiman, M., and Willett, R. 2003. Using the Hofstede-Gray framework to argue normatively for an extension of Islamic Corporate Reports. Malaysian Accounting Review, Vol. 2, No. 1, pp. 1-35.

Yaya, R. 2004. Would the Objectives and Characteristics of Islamic Accounting for Islamic Business Organizations Meet the Islamic Social-Economic Objectives?. JAAI, Vol. 8, No. 2, pp. 144-163. 